Бурдонос Людмила Іванівна кандидат економічних наук, доцент кафедри фінансів, обліку i оподаткування, «Університет імені Григорія Сковороди у Переяславі», вул. Сухомлинського, 30, м. Переяслав, 08400, тел.: (044) 293-11-10, https://orcid.org/0000-0002-1084-0826

Слюсар Світлана Тимофіївна кандидат економічних наук, доцент кафедри фінансів, обліку і оподаткування, «Університет імені Григорія Сковороди у Переяславі», вул. Сухомлинського, 30, м. Переяслав, 08400, тел.: (044) 293-11-10, https://orcid.org/0000-0002-3068-6387

\title{
КОНЦЕПТУАЛЬНІ ОСНОВИ ІНФОРМАЦЙНИХ СИСТЕМ ТА ТЕХНОЛОГІЙ, ЇХ МІСЦЕ ТА РОЛЬ В УПРАВЛІННІ НА ПІДПРИЕМСТВАХ
}

Анотація. В умовах структурних глобалізацій них змін відбувається різкий перехід від індустріального суспільства до інформаційного, розвиток якого безпосередньо пов'язаний $з$ інтенсифікацією інформаційних процесів, необхідністю збору, обробки і передачі величезних об'ємів інформації, перетворенням інформації у товар, як правило, значної вартості. Визначається роль процесів інформатизації при переході до інформаційного суспільства та інформаційної економіки.

Основні тенденції в світі інформаційних технологій та перспективи використання сучасних інформаційних технологій для управління бізнесом надають все більшої можливості оптимізувати і раціоналізувати управлінські функції на багатьох підприємствах різного масштабу, як малих так і середніх та профілю діяльності: виробничі, фінансові, сфери обслуговування і т.д., адже саме на підприємствах створюється необхідна суспільству продукція та зосереджуються і висококваліфіковані кадри, використовуються найсучасніші інтегровані інформаційні системи та інформаційні технології.

Поява всесвітньої мережі Інтернет, глобалізація економічного простору спричинила швидке зростання спілкувань між державами та континентами у різних сферах людського життя, до необхідності створення корпоративних серверів для надання різного роду інформації про підприємство на ринках.

Сучасні інформаційні системи і телекомунікаційні технології стають одним 3 найбільш прибуткових та швидко зростаючих секторів економіки. Інформація стає важливим виробничим і комерційним ресурсом (електронна комерція, комп'ютерна імітація та моделювання процесів і подій, Інтернеттехнологіi). 
В управлінні економікою підприємства інформаційна система виконує таку роль, як оброблення інформації в усіх аспектах для цілей управління, відстеження і формування необхідної внутрішньої і зовнішньої інформації для управління, накопичення, систематизації, збереження, відновлення всієї необхідної інформації, інформаційну, оптимізаційну, визначення основних показників техніко-економічного рівня виробництва і господарської діяльності, документальну.

Ключові слова: інформаційні системи підприємств, управління, облікові задачі, аналіз, планування, інформаційні технології, економічна інформація.

Burdonos Lyudmila Ivanivna $\mathrm{PhD}$ in Economics, Associate Professor, Chair of Finances, accounting and taxation Hryhorii Skovoroda University in Pereiaslav, Sukhomlinskoho St., 30, Pereiaslav, 08400, tel.: (044) 293-11-10, https://orcid.org/0000-0002-1084-0826

Sliusar Svitlana Tymofiivna PhD in Economics, Associate Professor, Chair of Finances, accounting and taxation Hryhorii Skovoroda University in Pereiaslav, Sukhomlinskoho St., 30, Pereiaslav, 08400, tel.: (044) 293-11-10, https://orcid.org/0000-0002-3068-6387

\section{CONCEPTUAL FUNDAMENTALS OF INFORMATION SYSTEMS AND TECHNOLOGIES, THEIR PLACE AND ROLE IN MANAGEMENT AT ENTERPRISES}

Abstract. In the context of structural globalization, there is a sharp transition from industrial to information society, the development of which is directly related to the intensification of information processes, the need to collect, process and transmit huge amounts of information, turning information into goods, usually significant value. The role of informatization processes in the transition to the information society and information economy is determined.

The main trends in the world of information technology and prospects for the use of modern information technology for business management provide an increasing opportunity to optimize and streamline management functions in many enterprises of different scales, both small and medium and business: production, finance, services, etc., because it is at enterprises that the products necessary for society are created and highly qualified personnel are concentrated, the most modern integrated information systems and information technologies are used.

The emergence of the World Wide Web, the globalization of the economic space has led to the rapid growth of communication between countries and continents in various spheres of human life, the need to create corporate servers to provide various information about the company in the markets. 
Modern information systems and telecommunications technologies are becoming one of the most profitable and fast-growing sectors of the economy. Information is becoming an important production and commercial resource (e-commerce, computer simulation and modeling of processes and events, Internet technology).

In managing the economy of the enterprise information system plays a role as information processing in all aspects for management purposes, tracking and generating the necessary internal and external information for management, accumulation, systematization, storage, recovery of all necessary information, information, optimization, definition of basic technical indicators -economic level of production and economic activity, documentary.

Keywords: enterprise information systems, management, accounting tasks, analysis, planning, information technology, economic information.

Постановка проблеми. В сучасних умовах господарювання актуальним $\epsilon$ життєздатність й бурхливий розвиток інформаційних систем та технологій, адже сучасний бізнес вкрай чуттєвий до помилок в управлінні, i для прийняття грамотного управлінського рішення в умовах невизначеності ринку необхідно постійно тримати під контролем різні аспекти фінансово-господарської діяльності підприємства та становище в ринковому середовищі, що швидко змінюється. Тому можна цілком обгрунтовано стверджувати, що сучасні інформаційні технології та системи підприємство, яке використовує в управлінні в жорстокій конкурентній боротьбі може перемогти.

Все більше на підприємствах, як державних так і приватних, банківських установах, страхових організаціях, комерційних установах, і т.д. України впроваджуються автоматизовані інформаційні системи i нові технології які дозволяють збільшити швидкість і якість обробки економічної , бухгалтерської, облікової та управлінської інформації при мінімальних затратах людських ресурсів.

Велику масу документації на підприємствах замінив багатофункціональний і оперативний електронний процес, який перетворює вхідні та звітні дані в інформацію та знання, відбувається вироблення мислення та здатності до використання процесного підходу при вирішенні облікових та фінансових задач на підприємствах та організаціях, що дає змогу забезпечити високий рівень гнучкості виробництва, його здатність миттєво реагувати на потреби ринку в умовах економічної нестабільності.

Аналіз останніх досліджень і публікацій. Важливі аспекти формування та розвитку інформаційних систем та інформаційних технологій на підприємствах в процесі управління висвітлюються такими українськими ученими як Т. Бова, К. Харіна, Н. Бусленко, В. Глушков, О. Івахненко, О. Черняк. Однак визначення ролі процесів інформатизації при переході до інформаційного суспільства та інформаційної економіки поки що не систематизовані і розроблені не в повному обсязі. 
Мета статті - дослідження особливостей інформаційних систем, як елемента управління економічними об'єктами в Україні та визначення основних тенденцій розвитку інформаційних технологій та перспектив використання сучасних IT для управління бізнесом.

Виклад основного матеріалу. Будь-яка інформаційна система має відповідний об'єкт, на який вона налаштована. На практиці у господарюванні підприємств виокремлюють різні фактори, які впливають на саму інформаційну систему та стратегію розвитку будь-якої організації, що придає їм ряд специфічних якостей.

Роль та функції які відіграють інформаційні системи на підприємствах повинні адаптуватися до методів та стилів, що використовуються в організації, бути максимально зручними, забезпечувати інформаційну незалежність менеджерам на різних рівнях в організації, що знижує практику підготовки багатоманітних довідок та неправдивої інформації, надавати повноту інформаційного забезпечення.

Існує також ясне розуміння того, що максимально ефективною буде система, що забезпечує безперервний інформаційний супровід виробничого циклу - від розробки нового виробу до випуску готової продукції [1, с. 97-112].

IT-мережі та комп'ютерні системи скоротили час, необхідний бухгалтерам для підготовки та подання фінансової інформації керівництву та зацікавленим сторонам. Це не тільки скоротило час виконання замовлення, необхідного для презентації фінансової інформації, але це також підвищило загальну ефективність і точність інформації [2].

За умов нормального функціонування системи обліковому персоналу немає потреби втручатися у інформаційний процес на будь-якому його етапі шляхом відображення проміжних даних [3, с. 48]

Оскільки складна система завжди багатофункціональна, інформаційну систему може бути класифіковано за різними ознаками: за рівнем управління (вищий, середній, оперативний); видом керованого ресурсу (основні засоби, матеріальні, трудові, фінансові й інформаційні ресурси); за сферою застосування (банківські інформаційні системи, статистичні, податкові, бухгалтерські, фондового ринку, страхові тощо); за функціями і стадіями управління [4].

IT - це цілісна система, яка функціонує в єдиному інформаційному просторі завдяки узгодженій роботі всіх іiі компонент. Реалізація системи та ії розгортання у часі забезпечує динаміку розвитку інформаційної технології, іï модифікацію, реструктуризацію, приєднання нових компонентів системи та модернізацію [5].

Успішне використання інформаційних систем вимагає розуміння ключових тенденцій розвитку бізнесу підприємства, при цьому вони мають забезпечуватися в основному:

- а) облікові функції - це не тільки доходи, витрати матеріалів і ведення банківських виписок, а й формування всіх первинних документів, необхідних для автоматичного створення будь-яких звітів; 


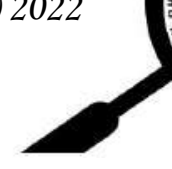

- б) аналітично-звітні можливості - передусім можливість швидкого i коректного створення нових і зміна наявних звітів за допомогою певних операцій;

- в) можливості для роботи зі звітами - швидке виконання звітів при великих обсягах даних, можливість одержувати в одному звіті всі необхідні дані за всіма підрозділами підприємства (склад, бухгалтерія, фінанси, виробництво, збут), групувати дані в будь-яких розрізах, деталізувати дані до будь-якого рівня;

- г) можливість об'єднання даних філіалів, підрозділів, дочірніх компаній або магазинів, обробки документів і звітів за кількома своїми компаніями, поділ і консолідація даних на рівні однієї/кількох/всіх компаній корпорації або інших'об'єктів обліку;

- д) можливості логічної, динамічної, статистичної та аналітичної обробки первинних даних, на основі якої має здійснюватися планування i прогнозування з використанням системи підтримки прийняття рішення;

- е) надійність і безпечність IC - втрата даних не може виникати за жодних обставин. Захист інформації - обмеження доступу до інформації будь-якими засобами має бути жорстко обмежене. Ресурсомісткість обладнання має бути таким, що підприємству не обов'язково нарощувати потужність устаткування при збільшенні даних або збільшенні кількості робочих місць.

Управління за допомогою інформаційних систем на підприємствах відбуваються на оперативному та тактичному рівнях. На тактичному рівні сюди відносять процедури середньострокового планування, аналізу i організації робіт, тобто на тактичному рівні розглядаються вже такі об'єкти, як, наприклад, зведення замовлень для формування виробничої програми. На відміну від тактичного рівня управління інформаційними системами на оперативному рівні керівництво має справу 3 окремим замовленням i супутніми його виконанню транзакціями.

Зростання ефективності роботи підприємства багато в чому залежить від економічної інформації, яка є одним з основних ресурсів, оскільки саме вона дозволяє встановлювати стратегічну мету i завдання підприємства та використовувати можливості, які при цьому відкриваються,координувати дії розрізнених підрозділів, спрямовуючи їх зусилля на досягнення поставлених цілей, приймати своєчасні і обгрунтовані управлінські рішення.

До економічної інформації пред'являються наступні вимоги: точність, однозначне сприйняття іiі; вірогідність, достовірність: припустимий рівень перекручування як тієї інформації, що надходить, так i результативної інформації, що відображає ефективність функціонування системи; оперативність, висока швидкість збору, обробки i передачі; кодування i декодування; документальність; захищеність; актуальність інформації для вироблення управлінських рішень, вироблення необхідних розрахунків в умовах, що змінюються; своєчасність, повнота і точність, надійність (з певним ризиком), комплексність, адресність, багаторазове використання [6, с. 38]. 
В своєму розвитку і вдосконаленні $\mathrm{IC}$ в різних галузях економіки мали різноманітну структуру компонентів, які значною мірою залежали від технікоексплуатаційних характеристик обчислювальної техніки, що в той чи інший період використовувалася для автоматизації економічних задач та наявністю функціональної і забезпечуючої частини, відповідно до декомпозиції системи на складові частини - підсистеми, що знаходяться у певних відносинах одна 3 одною.

Структура IC визначається розміщенням і взаємозв'язками іï елементів або частин при виконанні їхніх функцій. Структура залежить від величини системи та іiі складності. Величина системи характеризується не лише кількістю іiі елементів, а й зв'язками між ними. Складність визначається різноманітністю, неоднорідністю властивостей елементів та різною якістю зв'язків між ними (прямі, зворотні, нейтральні тощо) [7, с. 26].

На даний час в Україні під інформаційною системою в більшості випадків розуміють автоматизовані інформаційні системи, в пере важності це системи класів MRP, ERP, CRM, SRM.

Результати свідчать про такі тенденції їх розвитку AIC і комп’ютерних технологій: розподілена по віртуальній мережі, інтегрована з системою Internet система, що функціонує на основі стандартних інтерфейсів, яка об'єднує як програмні продукти для бізнесу, так і їх окремі компоненти, що призначаються для автономної роботи без зв'язку з глобальною мережею; системи управління середніми організаціями базуватимуться на можливості гнучкого управління замовленнями, підтримці повного життєвого циклу товарів та послуг, що виробляються, та на можливості інтеграції в якості компоненти в більш віртуальні підприємства, все більше підприємств стали і стають найпершими споживачами персональних комп'ютерів та автоматизованих систем i технологій, у тому числі й систем автоматизації бухгалтерського обліку.

AIC призначена для автоматизованого збирання, реєстрації, збереження, пошуку, оброблення та видачі інформації за запитами користувачів (управлінського персоналу). Вона складається 3 сукупності взаємозв'язаних компонентів: технічних засобів обробки i передачі даних (засобів обчислювальної техніки і зв'язку), методів і алгоритмів обробки у вигляді відповідного програмного забезпечення, масивів (наборів, баз) даних на різних носіях, персоналу і користувачів, об'єднаних за організаційно-структурними, тематичними, технологічними чи іншими ознаками для виконання автоматизованої обробки даних $з$ метою задоволення інформаційних потреб споживачів інформації. При цьому визначальним $\epsilon$ принцип орієнтації розробленого технічного, програмного, інформаційного забезпечення на потреби конкретних користувачів - управлінського персоналу, який $\epsilon$ учасником управлінського процесу [8, с. 26].

Згідно 3 нормативними документами під час створення автоматизованих інформаційних систем (AIC) у фінансово-кредитних установах необхідно 
дотримуватися таких основних принципів, як відкритості, стандартизації, сумісності , економічної ефективності, системності та безпеки:

1. За принципом відкритості АIC має створюватися 3 врахуванням можливості оновлення й поповнення ऑï функцій та складу без порушення функціонування AIC.

2. Принцип стандартизації. Під час створення систем мають бути раціонально застосовані стандартизовані елементи, проектні рішення, пакети прикладних програм тощо. Інформаційна система та іï елементи потребують стандартизації, аби можна було мінімізувати всі види витрат.

3. Принцип сумісності. Під час створення AIC мають бути реалізовані інформаційні інтерфейси, завдяки яким ця система зможе взаємодіяти 3 іншими системами згідно зі встановленими правилами.

4. Принцип економічної ефективності являє досягнення раціонального співвідношення між витратами на створення AIC i цільовими ефектами, включаючи кінцеві результати, отримані від автоматизації, які не завжди і не обов'язково мають набирати грошової форми, це можуть бути нові функції, час, певні зручності.

5. За принципу системності вкрай необхідно встановлювати такі зв'язки між структурними елементами інформаційної системи, які забезпечують i. сумісність та взаємодію з іншими системами. Отже, усі елементи, зв'язки , функції, проблеми управління й діяльності мають розглядатися як єдине ціле.

6.Принцип безпеки. Інформація має бути захищена як під час іiі безпосередньої обробки та зберігання в AIC, так і в моменти обміну між комп’ютерами. Також має бути виключена можливість несанкціонованого доступу до даних у системі.

В сучасних умовах на ринку програмного забезпечення існує безліч автоматизованих інформаційних систем, які засновані на загальних стандартах управління підприємством i представлені на ринку комп'ютерного забезпечення. Практично всі інформаційні системи мають стандартний набір інструментів для автоматизації наступних ділянок бухгалтерського обліку: модуль каса, облік товарно-матеріальних цінностей, валютний облік, основні засоби та нематеріальні активи, розрахунки з підзвітними особами, розрахунки по заробітній платі; розрахунки з бюджетом та позабюджетними фондами.

Найпопулярніша вітчизняна інформаційна система управління для малих підприємств - «1С: Підприємство» компанії «1С». Кількість підприємств в Україні, що працюють 3 продуктами компанії «1С» досягає декількох сотень тисяч. Це пояснюється не тільки якістю рішень, але i зразковою маркетинговою політикою компанії. Інструментарій розробки продукту: технологія V7, архітектура системи клієнт-серверна (на базі MS SQL Server), мова платформи V7 достатньо проста синтаксично.

Для обліку програми побудовані на основі реєстрації вихідних даних бухгалтерських проводок, породжуваних господарськими операціями. Для 
повного запису діяльності підприємства повині бути відображені всі проводки підприємства:

- вручну;

- за допомогою типових операцій, де кожна операція відповідає групі проводок, і тому коли суми деяких проводок розраховуються автоматично;

- 3 використанням первинних документів.

Інформаційні системи можуть використовувати майже будь-яку кількість довідників для організації аналітичного обліку і $\epsilon$ можливість ведення валютного обліку: тут використовуються довідники видів для валют та їх курсів.

В роботі 3 первинними документами у всіх програмах установлений великий набір стандартних первинних документів бухгалтерського обліку : накладних, рахунків на оплату, прибуткових і видаткових касових ордерів i т.д.т.д. Передбачена можливість створення і оптимізації первинних документів для всіх інших видів.

Побудова потужності інформаційних систем для вирішення облікових задач та проектування і функціонування інформаційних систем грунтуються на найважливіших положеннях та методах загальної теорії систем, системного проектування, теоріях інформації, що дозволяють забезпечувати взаємодію i сумісність інформаційних систем різних економічних об'єктів, економити працю, час і грошові кошти на проектування.

Найважливішими системотехнічними принципами $\epsilon$ : системність; інформаційний зворотний зв'язок; декомпозиція; безперервність розвитку інформаційної системи; сумісність; стандартизація і уніфікація; інтеграція; автоматизація інформаційних потоків і документообігу; ефективність.

Багатоплановість, складність і великі об'єми інформації, виступаючої в ролі інформаційної бази аналізу, вимагають використовування сучасних програмно-технічних засобів для їі обробки, тому проблема аналізу початкової інформації для прийняття рішень виявилася настільки склаждною, що з'явився окремий напрям інформаційних технологій - інформаційно-аналітичні системи (IAC).

Основними компонентами програмних засобів IAC являються засоби створення i супроводу інформаційного сховища - DWH (Data Warehouse), засоби оперативного аналізу - OLAP (On-line Analytical Processing), засоби інтелектуального аналізу - DMg (Data Mining). Кожен з цих компонентів має своє призначення та задачі.

Основними задачами DWH (Data Warehouse) збір інформації з баз даних, що відображають окремі бізнес-процеси, автоматизованих робітників місць, інформаційних систем і інших джерел, інформація з глобальних комп'ютерних мереж, як, наприклад, Інтернет. Інформація формується в різних форматах та має різноманітну структуру. Програмні засоби збирають інформацію i формують інформаційне сховище $з$ певною структурою і форматами даних. 


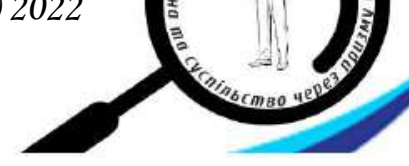

Могутні IAC налічують до 50 типів форматів, 3 якими може взаємодіяти інформаційна система.

Призначенням OLAP-аналізу $є$ витягання необхідної інформації 3 інформаційного сховища. Засоби OLAP забезпечують можливість сортування і вибірки даних за заданих умов, можуть задаватися різні якісні і кількісні умови. Засоби OLAP дозволяють виконувати аналітичні роботи різного характеру в наочній області користувача власними засобами, не вдаючись до програмування. Для опису специфічних для даного користувача аналітичних процесів можуть застосовуватися вбудовані засоби у вигляді мов високого рівня, графічних конструкторів, візуальних засобів, електронних таблиць 3 вбудованими функціями.

Засоби інтелектуального аналізу DMg (Data Mining) призначені для фундаментального аналітичного дослідження проблем в тій або іншій наочній області. Вимоги до часу менш жорсткі, ніж в OLAP-засобах. Засоби DMg є найскладнішою, інтелектуально насиченою частиною IAC, тому входять до складу найрозвиненіших IAC. При рішенні складних аналітичних задач використовуються могутні спеціальні програмні засоби, інструменти.

Основними задачами інтелектуального аналізу є: визначення значень чинників часу, локалізація подій або явищ по місцю виявлення взаємозалежностей, причинно-наслідкових зв'язків, асоціацій i аналогій, класифікація подій i ситуацій, визначення профілів різних чинників, прогнозування ходу процесів, подій.

Новітня інформаційна технологія PLM (Product Lifecycle Management), завдяки якій формалізація професійних знань користувачів в обчислювальному середовищі АРM, підприємства можуть інтегрувати в загальний процес життєдіяльності організації різні підрозділи, включаючи бухгалтерію, відділи фінансів і економіки, науково-дослідну i дослідноконструкторську роботу (НДДКР), а також виробництво, капітальне будівництво, матеріальне постачання, технічне обслуговування і ремонт.

Відбувається стратегічний підхід до організації управління підприємством, який використовує набір сумісних рішень для підтримки загального представлення інформації про продукт у процесі його створення, реалізації і експлуатації; у середовищі розширеного підприємства - починаючи від концепції створення продукту i закінчуючи його утилізацією - при інтеграції людських ресурсів, процесів і інформації

Висновки. Можна зробити висновки, що за своєю суттю інформаційна система є цілісною системою і має такі властивості в управлінні економікою:

1. залежно від виду і конкретного призначення інформаційна система має якості, які не можуть бути зведені до властивостей елементів, що іiі утворюють;

2. якісні характеристики конкретної інформаційної системи залежать від якісних характеристик їі елементів; 
3. між елементами інформаційної системи існує зв'язок, причому, коли відбувається зміна одного компонента системи, то це призводить до зміни іншого, а іноді і системи в цілому;

4. інформаційну систему як цілісне утворення характеризує впорядкованість елементів, які іiі утворюють, а також зв'язків і відношень між ними;

5. інформаційна система не існує ізольовано, ця властивість проявляється у взаємозв'язку системи з іншими системами [9, с. 80-86].

Складовими інформаційних технологій, які застосовують в управлінні на підприємстві виступають такі компоненти: технічні засоби (Т3); персонал, який спроможний грамотно працювати з інформацією й обчислювальною технікою, організація, що об'єднує засоби і персонал у єдиному процесі; інформаційні засобами, які здійснюють формування та видачу інформації у вигляді інформаційного продукту.

Застосування сучасних IT на будь-якому підприємстві впливають на підвищення якості й кількості послуг, на виникнення нових послуг; розвиток програмного забезпечення; створення умов для росту рівня життя населення; значне скорочення інвестиційних і управлінських витрат; розширення доступу до інформації 3 боку більшої кількості користувачів і удосконалення можливостей одержання, збереження, поширення інформації при використанні різноманітних джерел; збільшення ефективності багатонаціональних економічних контактів; створення нових можливостей зміцнення національної обороноздатності країни. зміну умов дії соціально-економічного механізму в результаті зміни умов праці і залучення інформації як предмета праці.

\section{Лimepamypa:}

1. Докучаев Д. Внедрение информационной системы как способ совершенствования бизнеспроцессов предприятия // САПР и графика. 2005. № 4. С. 97-112.

2. Концептуальні засади організації та методики обліку, аналізу, оподаткування та аудиту суб'єктів ринку в умовах новітніх інформаційних технологій та розвитку консалтингу: Матеріали I Регіональної науково-практичної конференції студентів, аспірантів і молодих вчених, проведеної на базі Тернопільського національного технічного університету імені Івана Пулюя. Тернопіль: ТНТУ, 2020. С. 90 https://oa.tntu.edu.ua/wpcontent/uploads/sites/58/2021/01/Матеріали-І-Регіональної-конференції.pdf

3. Муравський В. Документування в умовах повної автоматизації обліку // Бухгалтерський облік і аудит .2008. № 5. С. 48 - 52.

4. Івахненков С.В. Інформаційні технології в організації бухгалтерського обліку та аудиту: Навч. посіб., 4-те вид., випр. і доп. К.: Знання, 2010. 432 с. https://www.ivakhnenkovaudit.info/IT_in_control\&auditing.pdf

5. Плескач В.Л., Затонацька Т.Г. Інформаційні системи і технології на підприємствах: підручник. К. :Знання, 2011. 718 c. https://pidru4niki.com/1059110247701/informatika/ informatsiyni_sistemi_i_tehnologiyi_na_pidpriyemstvah

6. Пономаренко В. С., Журавльова I. В., Латишева I. Л. Інформаційні системи в управлінні персоналом. Навчальний посібник. Харків: Вид. ХНЕУ, 2008. С.38 
7. Бенько М.М. Інформаційні системи і технології в бухгалтерському обліку : монографія. К. : Київ. нац. торг.-екон. ун-т, 2010. С.26

8. Ушакова I. О. Інформаційні системи та технології на підприємстві : конспект лекцій. Харків : Вид. ХНЕУ, 2009. 128 c. http://www.repository.hneu.edu.ua/bitstream/ 123456789/3112/1/Конспект\%20лекцій.\%20Інформаційні\%20системи\%20та\%20технології\%20 на\%20підприємстві.\%20I.\%200.\%20Ушакова..pdf

9. Лазор Я. О. Поняття та види інформаційних систем. Вісник Національного університету "Львівська політехніка". Серія : Юридичні науки. 2016. № 837. С. 80-86. http://nbuv.gov.ua/UJRN/vnulpurn_2016_837_14

\section{References:}

1 Dokuchaev, D. (2005). Vnedrenye ynformatsyonnoi systembl kak sposob sovershenstvovanyia byznesprotsessov predpryiatyia . [Vnedrenye ynformatsyonnoi systemy kak sposob sovershenstvovanyia byznesprotsessov predpryiatyia]. SAPR y hrafyka - SAPR and graphics, 4, 97-112 [in Ukrainian].

2. Kontseptualni zasady orhanizatsii ta metodyky obliku, analizu, opodatkuvannia ta audytu subiektiv rynku v umovakh novitnikh informatsiinykh tekhnolohii ta rozvytku konsaltynhu. (2020). [Conceptual principles of organization and methods of accounting, analysis, taxation and audit of market participants in the latest information technology and consulting development]. Materialy I Rehionalnoi naukovo-praktychnoi konferentsii studentiv, aspirantiv $i$ molodykh vchenykh, provedenoi na bazi Ternopilskoho natsionalnoho tekhnichnoho universytetu imeni Ivana Puliuia: [Proceedings of the I Regional scientific-practical conference of students, graduate students and young scientists, held at Ternopil National Technical University named after Ivan Pulyuy]. Ternopil: TNTU, 90. Retrieved from https://oa.tntu.edu.ua/wp-content/uploads/sites/58/2021/01/ Materialy-I-Rehionalnoi-konferentsii.pdf [in Ukrainian].

3. Muravskyi, V. (2008). Dokumentuvannia v umovakh povnoi avtomatyzatsii obliku. [Documentation in terms of full automation of accounting]. Bukhhalterskyi oblik $i$ audit Accounting and Auditing, 5, 48 - 52 [in Ukrainian].

4. Ivakhnenkov, S.V. (2010). Informatsiini tekhnolohii v orhanizatsii bukhhalterskoho obliku ta audytu [ Information technology in the organization of accounting and auditing ]. Navch. posib., 4-tie vyd., vypr. i dop. K.: Znannia. Retrieved from https://www.ivakhnenkovaudit.info/IT_ in_control\&auditing.pdf [in Ukrainian].

5. Pleskach, V.L., Zatonatska, T.H. (2011). Informatsiini systemy $i$ tekhnolohii na pidpryiemstvakh [ Information systems and technologies in enterprises ] pidruchnyk. K. :Znannia. Retrieved from https://pidru4niki.com/1059110247701/informatika/informatsiyni_sistemi_i_ tehnologiyi_na_pidpriyemstvah [in Ukrainian].

6. Ponomarenko, V. S., Zhuravlova, I. V., Latysheva, I. L. (2008). Informatsiini systemy v upravlinni personalom. [Information systems in personnel management]. Navchalnyi posibnyk. Kharkiv: Vyd. KhNEU, 38 [in Ukrainian].

7. Benko, M.M. (2010). Informatsiini systemy $i$ tekhnolohii $v$ bukhhalterskomu obliku : [Information systems and technologies in accounting]. Monohrafiia. K. : Kyiv. nats. torh.-ekon. un-t,. 26, [in Ukrainian].

8. Ushakova, I. O. (2009) . Informatsiini systemy ta tekhnolohii na pidpryiemstvi [Information systems and technologies at the enterprise ]. Konspekt lektsii. Kharkiv : Vyd. KhNEU. Retrieved from http://www.repository.hneu.edu.ua/bitstream/123456789/3112/1/ Konspekt\%20lektsii.\%20Informatsiini\%20systemy\%20ta\%20tekhnolohii\%20na\%20pidpryiemstvi. \%20I.\%200.\%20Ushakova..pdf [in Ukrainian].

9. Lazor, Ya. O. (2016). Poniattia ta vydy informatsiinykh system. [ Concepts and types of information systems ]. Visnyk Natsionalnoho universytetu "Lvivska politekhnika" - Bulletin of the National University "Lviv Polytechnic". Seriia : Yurydychni nauky, 837, 80-86. Retrieved from http://nbuv.gov.ua/UJRN/vnulpurn_2016_837_14 [in Ukrainian]. 